\title{
SSR マーカーによるいもち病菌戋場分離集団の遺伝的分化の解析
}

\author{
善林 董 $1 *$ ・鬼頭 英樹 ${ }^{1}$ ・鈴木 文彦 ${ }^{2}$
}

\begin{abstract}
ZENBAYASHI-SAWATA, K. ${ }^{*}$, KITO, H. ${ }^{1}$ and SUZUKI, F. ${ }^{2}$ (2014). Analysis of genetic differentiation in field populations of Pyricularia oryzae by SSR markers. J. Phytolpathol. 80: 81-87.

Rice blast, caused by Pyricularia oryzae, is the most prevalent and widespread disease of rice in Japan. In this study, simple sequence repeat (SSR) markers were used to discriminate among three field populations of rice blast, which consisted of isolates collected from three respective plots with two cultivars during the growing seasons. In total, 302 isolates of $P$. oryzae genotypes were found with 8 SSR markers and used in population genetic analyses. Collected isolates were classified into three populations by field plot, and each population was separated into subpopulations according to the blast epidemic stage. Haplotypic diversity of the populations ranged from 0.535 to 0.904 , revealing that genetic diversity in the field populations was high. All three populations were significantly differentiated according to pairwise $F_{\mathrm{ST}}$ and $R_{\mathrm{ST}}$ comparisons, but no differentiation was detected among subpopulations grouped by epidemic stages in the same plot. A migration event was detected by SSR genotyping of the isolates between neighboring plots. A phylogenic tree based on a minimum spanning tree algorithm also suggested migration of the fungus and showed that the direction of evolution differed among populations of the same cultivar located spatially distant from adjacent plants of different cultivars. From these results, SSR markers may enable us not only to discriminate field populations of $P$. oryzae that are genetically similar, but also to evaluate genetic processes such as gene flow, genetic drift, mutation and natural selection of the populations.
\end{abstract}

(Received November 8, 2012; Accepted August 26, 2013)

Key words: genetic diversity, Pyricularia oryzae, population structure, SSR

\section{緒言}

イネいもち病（病原菌 Pyricularia oryzae Cavara, telemorph : Magnaporthe oryzae) はイネの重要病害であり, 毎年, 本病 の被害を軽減するために多額の資材や防除薬剤が使用され ている。これらの防除資材に依らない病害防除法として, 長い間, 外国稲を含むイネの保有するいもち病真性抵抗性 遺伝子の国内品種への導入が行われてきた。しかし，それ ら抵抗性遺伝子の多くは品種普及後数年で無効化すること が報告されて打り（伊藤，1967; 田中ら，1970; 山田ら，1970）, 近年では，レース変動に依存せず，より無効化しにくいと 考兄られる量的形質であるいもち病抵抗性（固場抵抗性） の導入が精力的に行われている（坂ら，2007，2010; 山口ら， 2005). 抵抗性品種の罹病化機構の解析の結果, 真性抵抗性
遺伝子とそれに対応するいもち病菌の非病原力遺伝子間の 相互作用が明らかになってきて拈り（Jia et al., 2000）, 今後 真性抵抗性遺伝子については, 宿主一病原体相互作用の 解析に基づいた罹病化機構の解明が進むものと期待される. しかし, 固場抵抗性遺伝子については, 単離された遺伝子 の数も少なく（Fukuoka et al., 2009; Hayashi et al., 2010), 宿 主と病原菌との相互作用についての知見は未代乏しい.

持続的な病害抵抗性遺伝子の利用方法を確立するために は, 抵抗性遺伝子の機能解析だけでなく, 病原性変異を含 めた病原菌集団の遺伝的変化, 寸なわち, 圃場の病原菌集 団に扣ける進化の機構を明らかにしなければならない. Spitze（1993）は，集団内の特定形質の遺伝的進化を正しく 評価するためには，中立的に進化するゲノム領域の遺伝的 変異の程度やその速度を量的に評価したらえで，特定形質

\footnotetext{
1 (独) 農業・食品産業技術総合研究機構東北農業研究センター（† 014-0102 秋田県大仙市四ッ屋字下古道 3） NARO Tohoku Agricultural Research Center, 3 Shimofurumichi, Yotsuya, Daisen, Akita 014-0102, Japan

2 (独) 農業・食品産業技術総合研究機構中央農業総合研究センター（† 305-8666 茨城県つくば市観音台 3-1-1） NARO Agricultural Research Center, 3-1-1 Kannondai, Tsukuba, Ibaraki 305-8666, Japan

* Corresponding author (E-mail: kaoruz@affrc.go.jp)
} 
をコードする遺伝子領域におけるとれらと比較することが 重要であると述べている. いもち病菌に拈いては, 高橋ら （2008）が圃場に抢忊る病原性変異いもち病菌の出現頻度を 明らかにしているが，中立的に進化する遺伝的指標を用い た圈場分離集団に抢ける集団遺伝学的な構造解析はほとん ど行われて扣らず，いもち病菌集団の多様性や進化速度を 理解するための基本情報が不足している.

一方, 近年, 病原菌個体を高精度で識別できる分子マー カ一の開発が進められ, これを利用して圃場の病原菌集団 の構造解析を行い, 得られた知見を抵抗性品種に対する病 原菌の適応程度の予測に用いる研究が急速に発展している (McDonald et al., 1996; Zhan et al., 2002). イネいもち病菌で は, 鈴木らが, 日本産いもち病菌の識別が可能な Pot2 repPCR やSSR (Simple Sequence Repeat)を開発している (Suzuki et al., 2010; 鈴木ら, 2012). 特に, SSR については, 西日本 16 県のいもち病菌集団の遺伝的多様性や遺伝的距離の解析 から, 本邦いもち病菌の集団遺伝学的研究に有効であるこ とが報告されている（鈴木ら，2012）．

いもち病の発生と伝搬には, 種子伝染と栽培期間中の胞 子飛散による空気伝染が大きく影響することから，種籾の 由来が同じ（もしくは近い）圃場や，品種が異なっていて も隣接する國場間で生じるいもち病菌の個体群はより近縁 であることが予想される，そこで本研究では，種籾の生産 地域が同じ同一品種の栽培圃場間や，隣接した異品種栽培 圃場間から採集された菌株からなるいもち病菌集団に沶い て, 現時点でもっとも個体識別能が高いと考兄られる SSR マーカーが，集団の構造解析に利用可能かを検証すること を主目的として, 2 地点 3 围場のいもち病菌集団について, 1) 同一圃場内における, 作期を通した本菌集団構造や多様度 の変化 2）近接する 2 圃場に拈ける菌の移出入の検出 3） 3 圃場のいもち病菌集団の遺伝的距離, について解析した.

\section{材料および方法}

試験戋場および耕種概要 試験は 2009 年に行った。固場 に発生したいもち病菌を経時的に採集する戋場として, 東 北農業研究七ンタ一大仙研究拠点 (秋田県大仙市) 内の YA 圃場（10 a）扔よび，YA 圃場から直線距離で約 $1 \mathrm{~km}$ 離れ, 間に国道, 線路扮よび住宅地が存在する農家圃場 TA（70 a を設定した（Fig. 1)。両圃場ともに JA 打ばこから購入した 種子消毒 (ヘルシードスターナ吹付け) 済久「あきたこまち」 種子を育苗した苗を移植した。 購入した種子は同一採種組 合産であるが，採種農家は異なっていた．育苗期および移 植後の追肥，除草剂捖よび殺虫剂による防除は，秋田県仙 北地域の農家慣行に準じて行った。 いもち病防除は, YA 固

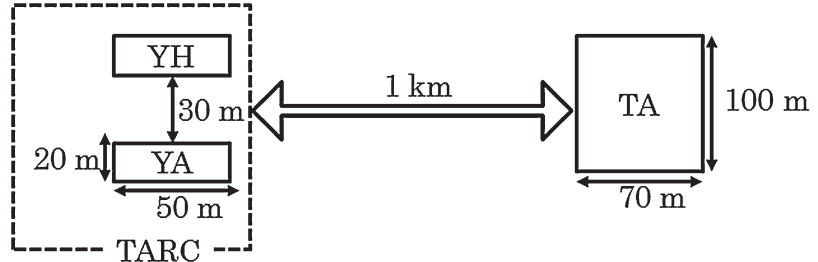

Fig. 1. Location of sampling plots in Akita Prefecture in Japan. YA and $\mathrm{YH}$ are located in Tohoku Agricultural Research Center (TARC); TA is a farmer's field $\sim 1 \mathrm{~km}$ east of TARC.

場は 6 月 19 日にプロベナゾール粒剂（有効成分：プロベナ ゾール 8.0\%）を $3 \mathrm{~kg} / 10 \mathrm{a}, 7$ 月 21 日にピロキロン粒剤（同: ピロキロン $5.0 \%) を 3 \mathrm{~kg} / 10 \mathrm{a}$ 散布した. TA 圑場は緑化期 (4 月下旬) にカルプロパミド箱粒剤 (同:カルプロパミド $4.0 \%$ ) を $10 \mathrm{~g}$ 箱，移植時（5 月下旬）にプロベナゾール・フィプロ ニル箱粒剤（同:プロベナゾール $24.0 \%$, フィプロニル $0.6 \%$ ) を $50 \mathrm{~g} /$ 箱処理し, 穂いもち防除は無人へリを用いた共同防 除によって 7 月下旬にフサライドフロアブル（同：フサラ イド 20.0\%）を散布した。 また，所内固場で早期にいもち 病が発生した圃場からも葉いもち病斑抒よび穗いもち罹病 部位の採集を行った。この圈場（YH: $10 \mathrm{a} ）$ はA と約 $30 \mathrm{~m}$ の距離に位置し, 多数の品種が栽培されていた。葉打よび 穂いもちは, 、もち病防除が実施されていなかった品種「ひ とめぼれ」栽培区から採集した。 それぞれから分離した菌 株は，固場別集団として YA，YH およびTA と表記した。

いもち病の発生といもち病菌採集 本研究では, 小林 （1984）が報告している定義に準じ，伝染第 1 㐨よび第 2 世 代病斑を葉いもち発生初期の病斑, 第 3 世代以降を葉いも ち発生盛期の病斑とし, 穂首, 枝梗抒よび籾のいもちを穗 いもちとしてこれらを採集した，発生時期別の分集団を表 す場合は，葉いもち発生初期を $\mathrm{E}$, 盛期を $\mathrm{L}$, 穂いもちを $\mathrm{P}$ として，固場名と組み合わせて「YA-E」のように表記した。 菌株採集方法は, 発病株数が少ない発生初期とそれ以降で 異なる方法を用いた。 すなわち，発生初期は，YAについて は固場内を $5 \mathrm{~m} \times 5 \mathrm{~m}$ の 36 ブロックに分け，1ブロックお きに全株を調査し，ブロック内で 1 回の採集につき 10 病斑 を超えないよう無作為に採集した，TAについては，1ブロッ クを $10 \mathrm{~m} \times 20 \mathrm{~m}$ として，YA と同様に採集した．围場全体 に発病が広がった発生盛期以降拉よび穂いもちについては, YA は縦横 $3.6 \mathrm{~m}$ 捄き, TA は同 $10 \mathrm{~m}$ 扣きに中心株周辺から 1 病斑を採集した。 $\mathrm{YH}$ 戋場については，葉いもちは早期に 発生が認められた第一世代病斑 4 菌株のみを採集し, 穂い もちは区内から任意に罹病穂を採集して脱穀したのち，無 作為に選んだ罹病籾から分離した。菌株は，1病斑あるいは 1 罹病穂（籾）から，単胞子分離により 1 採集地点あたり 1 
菌株を分離し，YA，YH拈よびTAからそれぞれ 160，62， 80 の計 302 菌株を得た。

DNA 抽出および SSR マーカーの検出 各菌株はPDA 培 地で培養後, 菌糸を掻き取り DNeasy Plant mini kit（Qiagen） を用いて全 DNA を抽出した. DNA は濃度を $10 〜 20 \mathrm{ng} / \mu \mathrm{l}$ に調整し, マルチプレックスマーカー化したSSRを用いた 解析を行っている秋田県立大学バイオテクノロジーセン ターに委託して, 鈴木ら（2012）が報告している 12 座の $\mathrm{SSR}$ マーカーのPCR 産物サイズをシーケンスにより確定し た. 得られた各 SSR マーカーの PCR 産物サイズデータにつ いては，末端に付加された 1 塩基の有無によるサイズのず れを補正後, 最終的な SSR マーカーのアリルサイズとして データ解析に用いた.

データ解析 SSR マーカーのアリルサイズを組み合わせ たものを, 各菌株のハプロタイプとし, 全 302 菌株について, 分集団拈よび全集団のハプロタイプ数, 八プロタイプ多様 度（Diversity）（Nei, 1987）を GenAlEx ver. 6.1（Peakall and Smouse, 2006）により計算した。 また, Arlequin ver. 3.1.1 （Excoffier et al., 2005）を用いて，集団拈よび分集団間のア リルの出現頻度に基づく集団分化指数 $\mathrm{F}_{\mathrm{ST}}$ 扎よびアリルサイ ズに基づいた遺伝子分化係数 $\mathrm{R}_{\mathrm{ST}}$ （Slatkin, 1995）を算出し，集 団間のペアワイズ $\mathrm{F}_{\mathrm{ST}}$ 扎よび $\mathrm{R}_{\mathrm{ST}}$ を計算して集団分化を検定 した。また Minimum spanning network 法を用いてハプロタ イプ系統樹を作成し，TreeView（ver. 0.4）を使用して系統 樹を描画した.

\section{結果}

\section{いもち病の発病および解析集団個体数}

試験圃場で最も早く葉いもちが発生したのは YH 固場で, 6 月 29 日に「ひとめぼれ」で特定の株に第一世代の病斑が 出現し，その後無防除区を中心に発病が進んで葉および穂い もちともに多発生となった。 YA 固場では，7月9日に全株調 査で 4 株に第一世代病斑がみられ，その後病勢は進展して 穂いもちは中発生程度となった。 TA 圃場でも第一世代病斑 の出現日は 7 月 9 日と推定され, 葉および穂いもちの発病 程度は小発生であった. 菌株は, 1 病斑あるいは 1 罹病穂 $($ 籾) から単胞子分離により確立し，YA，YH抽び ぞれ 160，62 および 80 の計 302 菌株を得た。これら固場別 の集団拉よび，菌株の世代により各集団を3つに分けた分 集団を構成する個体（菌株）数を Table 1 に示した.

\section{SSR マーカーの対立遺伝子座数と分集団の遺伝的多様性}

全 302 菌株に打ける 12 座の SSR マーカーのアリル数は, 最も少ない Mgms07 で 1, 最も多い ms87-88 で 27 個であった (Table 2). 検出されたアリルサイズ範囲が，鈴木ら（2012） が報告している期待值（Expected size）と異なるものもあっ たが，これは期待值がギアナ産いもち病菌株 Guy11 に由来 する菌株 70-15 の塩基配列に基づいて抢り，日本の固場分 離菌とは遺伝的背景が大きく異なることが原因と考学られ る.アリル数が中程度であった Mgms01，02，04，06，08， 09, 14 およびMs99-100の8 マーカーをマーカーセットA,

Table 1. Haplotype number and diversity of Pyricularia oryzae populations in Akita Prefecture based on different sets of SSR markers

\begin{tabular}{|c|c|c|c|c|c|c|c|c|}
\hline \multirow{3}{*}{$\begin{array}{l}\text { Sample location } \\
\text { (Rice cultivar) }\end{array}$} & \multirow{3}{*}{ Subpopulation } & \multirow{3}{*}{ Source } & \multirow{3}{*}{$\begin{array}{l}\text { Sampling } \\
\text { time }\end{array}$} & \multirow{3}{*}{$\begin{array}{l}\text { No. of } \\
\text { isolates }\end{array}$} & \multicolumn{4}{|c|}{ Haplotype } \\
\hline & & & & & \multicolumn{2}{|c|}{ Marker set ${ }^{\mathrm{a})} \mathrm{A}+\mathrm{B}$} & \multicolumn{2}{|c|}{ Marker set A } \\
\hline & & & & & Number & Diversity $^{\mathrm{b})}$ & Number & Diversity \\
\hline \multirow{4}{*}{$\begin{array}{c}\text { YA } \\
\text { (Akitakomachi) }\end{array}$} & YA-E & Leaf & Early & 70 & 31 & 0.911 & 22 & 0.871 \\
\hline & YA-L & Leaf & Late & 66 & $38(11)^{\mathrm{c})}$ & 0.915 & $18(12)$ & 0.844 \\
\hline & YA-P & Panicle & & 24 & $15(10)$ & 0.910 & $8(7)$ & 0.799 \\
\hline & total & & & 160 & 65 & 0.946 & 27 & 0.863 \\
\hline \multirow{3}{*}{$\begin{array}{c}\text { YH } \\
\text { (Hitomebore) }\end{array}$} & YH-E & Leaf & Early & 4 & 2 & 0.500 & 1 & 0.000 \\
\hline & YH-P & Panicle & & 58 & 47 & 0.976 & 23 & 0.904 \\
\hline & total & & & 62 & 47 & 0.973 & 23 & 0.904 \\
\hline \multirow{4}{*}{$\begin{array}{c}\text { TA } \\
\text { (Akitakomachi) }\end{array}$} & TA-E & Leaf & Early & 35 & 17 & 0.890 & 15 & 0.816 \\
\hline & TA-L & Leaf & Late & 21 & $16(4)$ & 0.902 & $7(4)$ & 0.535 \\
\hline & TA-P & Panicle & & 24 & $16(4)$ & 0.906 & $10(4)$ & 0.764 \\
\hline & total & & & 80 & 41 & 0.946 & 24 & 0.755 \\
\hline
\end{tabular}

a) The components of the marker set are shown in Table 2 .

b) Diversity $=1-\sum(p i)^{2}$, where $p i$ is the frequency of the $i$ th haplotype for the population and $\sum(p i)^{2}$ is the sum of the squared frequency of the haplotype in the population.

c) Number in parentheses indicates the number of haplotypes common to the two subpopulations. For example, isolates in subpopulation YA-L are classified into 38 haplotypes by marker set $\mathrm{A}+\mathrm{B}$, and 11 of these haplotypes are common to YA-E. 
Table 2. Number of alleles and size of the 12 SSR loci detected in Pyricularia oryzae isolates

\begin{tabular}{ccccc}
\hline $\begin{array}{c}\text { Marker } \\
\text { set }^{\text {a) }}\end{array}$ & $\begin{array}{c}\text { SSR } \\
\text { locus }\end{array}$ & $\begin{array}{c}\text { No. of } \\
\text { alleles }\end{array}$ & $\begin{array}{c}\text { Expected } \\
\text { size (bp) })^{\mathrm{b})}\end{array}$ & $\begin{array}{c}\text { Observed size } \\
\text { range (bp) }\end{array}$ \\
\hline \multirow{4}{*}{ A } & Mgms01 & 2 & 245 & $216-219$ \\
& Mgms02 & 10 & 348 & $249-328$ \\
& Mgms04 & 3 & 245 & $254-266$ \\
& Mgms06 & 3 & 229 & $243-256$ \\
& Mgms08 & 9 & 273 & $217-247$ \\
& Mgms09 & 6 & 220 & $213-228$ \\
& ms99-100 & 10 & 225 & $236-284$ \\
B & Mgms13 & 17 & 248 & $235-278$ \\
& Mgms15 & 16 & 213 & $179-241$ \\
& ms87-88 & 27 & 203 & $158-295$ \\
& Mgms07 & 1 & 228 & 212 \\
\hline
\end{tabular}

a) Marker set A: Mgms01, Mgms02, Mgms04, Mgms06, Mgms08, Mgms09, Mgms14, and ms99-100; marker set B: Mgms13, Mgms15, ms87-88, and Mgms07.

b) SSR loci and their expected size were obtained from Suzuki $e t$ al. (2012).

それ以外をマーカーセット B とし， 12 座すべての SSR マー カー $(\mathrm{A}+\mathrm{B})$ を用いてハプロタイプによる菌株の識別を行っ た. その結果, もっとも遺伝的多様度の高い YH-P では 58 菌 株が 47 種類の八プロタイプに類別されたのをはじめ, 各 分集団内の菌株は非常に多くのハプロタイプに類別された

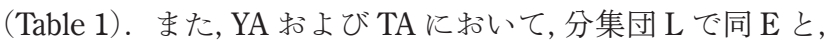
分集団 $\mathrm{P}$ で同 L との間で共通して検出されたハプロタイプ は, YA-L で 38 種類中 11 種類, YA-P で 15 種類中 10 種類, TA-L および TA-P で 16 種類中 4 種類であった（Table 1). また，同一固場内の菌株について，アリルサイズの変化を 調査したところ, Table 3 に例を示したアリル数の多い 3 種 のマーカーに扣いて, SSR の反復数が 1 個増減して新たな
アリルが生じたことにより，異なるハプロタイプとなる菌 株が観察された. このことから, アリル数の多いマーカーは, 一作期内の菌増殖の過程で変異している可能性があると考 えられた。また，Mgms07 はアリル数が 1 で，多型が検出 されなかった。 そこで，マーカーセットAのみを用いてハ プロタイプ分類を行ったところ，YA，YH扎よび TA はそれ ぞれ 27,23 および 24 種類のハプロタイプに類別され，集 団拈よび分集団の遺伝子多様度はYH-Eを除き $0.535 \sim 0.904$ の範囲の值を示した（Table 1)。これらの值から，宿主品種 （伝染源となる罹病種子）や固場の違いによるいもち病菌集 団の差異を識別するのに十分な多様性は確保されていると 判断し, 以後, 集団拈よび分集団の構造解析にはこの 8 マー カーを用いた.

\section{品種および圃場におけるいもち病菌集団の遺伝構造解析}

$\mathrm{YA}, \mathrm{YH}$ および TA のいもち病菌集団について, ペアワイ ズ $\mathrm{F}_{\mathrm{ST}}$ を算出した結果，いずれの組み合わせに拈いてもぺ ア集団間で有意な遺伝的分化が認められ，この 3 集団は遺 伝的に異なる集団であることが明らかとなった（Table 4). 一方，実際のアリルサイズを用いて解析した分化程度 $\left(\mathrm{R}_{\mathrm{ST}}\right)$

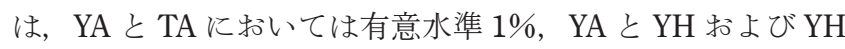
と TA の組み合わせでは有意水準 $5 \%$ で遺伝的分化を支持す る結果となった（Table 4).

Table 4. Matrix of exact tests of genetic pairwise differentiation among three collection sites using $F_{\mathrm{ST}}$ (below diagonal) and $R_{\mathrm{ST}}$ (above diagonal)

\begin{tabular}{cccc}
\hline Site & YA & YH & TA \\
\hline YA & - & $0.018^{*}$ & $0.125^{* *}$ \\
YH & $0.059^{* *}$ & - & $0.033^{*}$ \\
TA & $0.283^{* *}$ & $0.198^{* *}$ & - \\
\hline
\end{tabular}

$* P<0.05, * * P<0.01$ after Bonferroni corrections. Data were analyzed using Arlequin ver. 3. 1.

Table 3. Example of observed PCR product size (bp) for the SSR loci in rice blast isolates collected in the field

\begin{tabular}{lccccccccccccccc}
\hline & Locus $^{\text {a) }}$ & Mgms & Mgms & Mgms & Mgms & Mgms & Mgms & Mgms & ms & Mgms & Mgms & Mgms & $m s$ \\
Isolate & $\begin{array}{c}\text { Repeat } \\
\text { motif }\end{array}$ & CAG & GGTA & TGT & TAC & CAA & TTC & GTAG & CAA & CAA & AG & TC & TGC \\
\hline YA-E-02 & & 216 & 277 & 257 & 244 & 212 & 217 & 260 & 262 & 235 & 173 & $\underline{209}$ & 159 \\
YA-L-63 & 216 & 277 & 257 & 244 & 212 & 217 & 260 & 262 & 235 & 173 & $\underline{211}$ & 159 \\
\hdashline YA-L-90 & 216 & 277 & 254 & 244 & 212 & 217 & 264 & 259 & 229 & $\underline{165}$ & 211 & 215 \\
YA-P-164 & 216 & 277 & 254 & 244 & 212 & 217 & 264 & 259 & 229 & $\underline{163}$ & 211 & 215 \\
\hline
\end{tabular}

a) Loci and repeat motifs were obtained from Suzuki et al. (2012). Repeat motif of $m s 99-100$ was modified based on the current genome sequence of isolate 70-15 in Magnaporthe grisea Database. (http://www. broadinstitute. org/annotation/genome/magnaporthe_grisea/ MultiHome. html, accessed July 2013).

b) Numbers in the table are the observed PCR product size (bp) of the SSR loci in the isolates; underlines indicate that different sizes were observed probably due to the change of repeat units among the isolates. 
Table 5. Pairwise comparison of genetic differentiation $\left(F_{\mathrm{ST}}\right)$ among eight subpopulations of Pyricularia oryzae

\begin{tabular}{|c|c|c|c|c|c|c|c|}
\hline Subpopulation & YA-E & YA-L & YA-P & YH-E & YH-P & TA-E & TA-L \\
\hline \multicolumn{8}{|l|}{ YA-E } \\
\hline YA-L & 0.007 & & & & & & \\
\hline YA-P & 0.016 & -0.004 & & & & & \\
\hline YH-E & $0.220^{*}$ & $0.156^{*}$ & $0.178 *$ & & & & \\
\hline YH-P & $0.040 * *$ & $0.059 * *$ & $0.054 * *$ & $0.303 * *$ & & & \\
\hline TA-E & $0.110^{* * *}$ & $0.140 * *$ & $0.162 * *$ & $0.385^{* *}$ & $0.106^{* *}$ & & \\
\hline TA-L & $0.208 * *$ & $0.252^{* *}$ & $0.298 * *$ & $0.575 * *$ & $0.227 * *$ & 0.042 & \\
\hline TA-P & $0.126 * *$ & $0.155^{* *}$ & $0.183 * *$ & $0.422 * *$ & $0.119 * *$ & -0.006 & 0.026 \\
\hline
\end{tabular}

$* P<0.05, * * P<0.01$ after Bonferroni corrections. Data were analyzed using Arlequin ver. 3. 1 .

次に，分集団についてペアワイズ $\mathrm{F}_{\mathrm{ST}}$ を求めたところ，YA と TA では，同一圃場内の分集団間で有意な遺伝的分化は認 められなかった。 YHについてはYH-E と YH-P間で $\mathrm{F}_{\mathrm{ST}}$ が 0.303 と比較的大きい值を示したが，これは YH-E が早期発 生の 4 病斑のみであり, サンプリング数の不足によるハプ ロタイプの偏りが影響した可能性が考えられた. 一方，異 なる圃場間に拈いては，いずれの組み合わせにおいても遺 伝的分化が検出された（Table 5).

\section{系統樹による遺伝的類縁関係の解析}

ハプロタイプペアについてアリルの異なるマーカー数を ハプロタイプ間距離として用い, minimun spanning tree（最 小木）アルゴリズムによりネットワーク系統樹を作成した (Fig. 2). その結果，3 集団に共通するハプロタイプは系統 樹の中心に近いところに位置していた． 2 集団に共通するハ プロタイプについては，YA と TA で共通するハプロタイプ, すなわち同一品種から得た菌株のハプロタイプは概ね図の 右側に，YA と YH すなわち品種は異なるが近接した圃場か
ら得た菌株のハプロタイプは左側に配置される結果となっ た. TA と $\mathrm{YH}$ 間のみに共通するハプロタイプはなかった. また，Fig. 2 で検出されたハプロタイプI-1 は， YH-Eの 4 菌株が属するハプロタイプであり，YAと YH集団に拉いて 検出頻度の高いハプロタイプであった。

\section{考察}

今回, 自然発生条件下で増殖したイネいもち病菌の集団 の識別に，鈴木ら（2012）の開発した SSR マーカーが利用 できるかる検討した，一般的に，SSRの突然変異頻度は遺 伝子のコード領域と比較して高いと言われている（Thuillet et al., 2001)。また， い子ち病菌の圃場にお打る増殖は指数 関数的であり，一作期内で個体数が急激に増加するとされ る (小林, 1984)。これらの知見から, 固場分離菌株は多様 なハプロタイプに類別されることが予想されたが，本研究 の結果，アリル多様度の高いマーカーを用いて菌株のハプ ロタイプを類別すると，一作期内で菌の世代が進むにつれ
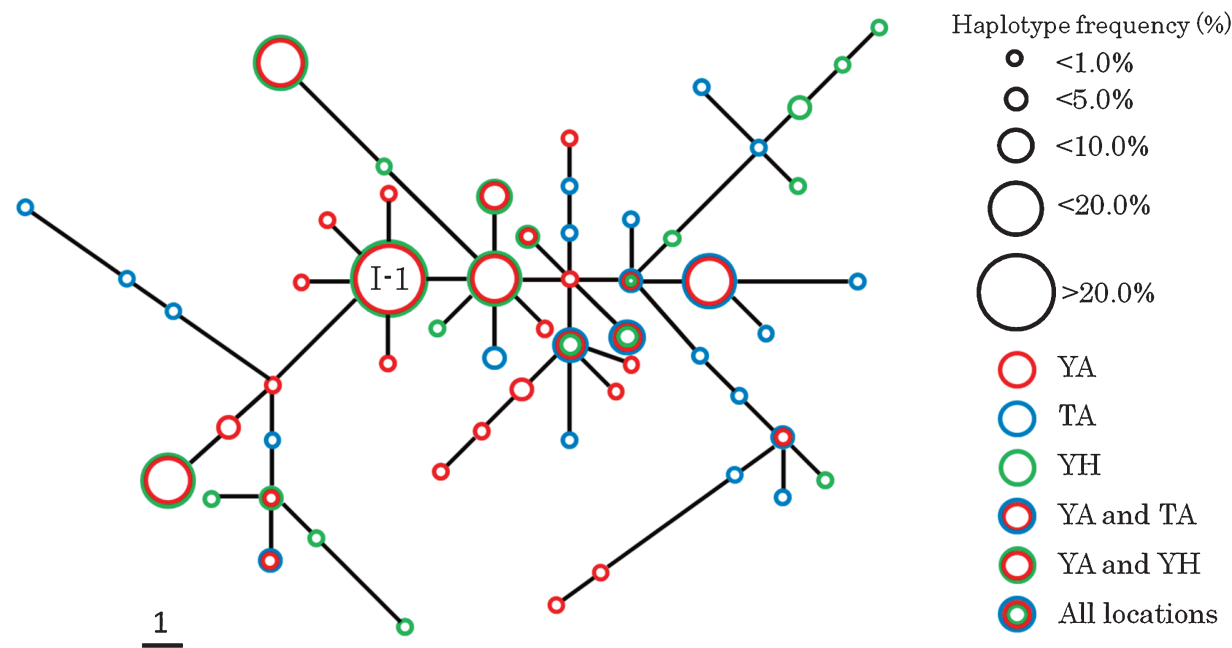

Fig. 2. Minimum spanning tree of three Pyricularia oryzae populations. Haplotypes represented by red, blue and green circles were collected from YA, TA and YH field, respectively. Circle size corresponds to proportion of haplotype frequency. 
て新たなハプロタイプが検出され，世代間で共通するハプ ロタイプ割合はそれほど高くなかった（Table 1)。また，ア リル多様度の高いマーカーに拈いては，一作期内でもいも ち病菌が増殖する過程で変異している可能性が考えられた (Table 3). これらの結果から, Guichoux et al. (2011) が述 ベているよらに, SSR マーカーを用いることは，短期間で の集団の変化を捉えることができる半面, 菌株の親子解析 や長期的な進化の解析では, 誤った判断をする可能性があ る. したがって, 解析目的に適したマーカーを選択するた めには, 突然変異頻度の推定を含めたマーカー情報をさら に充実させる必要があると考光られる。

そこで本研究では, アリルサイズ多型が中程度のマーカー 8 個を選択し，それらを組久合わせて固場別の集団および分 集団のハプロタイプ多様度を解析した. その結果, いもち 病菌集団は, 発生の初期から高い遺伝的多様性を持って括 り, 世代が経過しても多様度の顕著な増減は検出されなかっ た. 分集団間でのハプロタイプの変化をみると, 時間的に 近い 2 つ分集団間，あるいはどの分集団間でも検出され るハプロタイプがある一方, 特に TA 固場では 1 つの分集団 でのみ検出されるハプロタイプも多かったことから，いも ち病菌集団では, 世代の経過時に多様なハプロタイプの出 現执よび消失が起こって扣り, 全体として一定の多様度が 保たれていると考光られた。 また，八プロタイプデータを 用いてペアワイズ $\mathrm{F}_{\mathrm{ST}}$ および $\mathrm{R}_{\mathrm{ST}}$ を解析した結果, $\mathrm{YA}$ と $\mathrm{TA}$ 集団は遺伝的に異なる集団であると判定されたことから， 選択した 8 マーカーを用いることで，同一品種だが種籾の 由来扎よび栽培農家が異なり, かつ互いの圃場への菌の移 出入が萎とんどないと考えられる程度に距離がある 2 圃場 間のいもち病菌集団を識別できることが明らかとなった (Table 4, 5)。 また，栽培品種が異なり近接した YA と YH 固 場間に括いても同菌集団の遺伝的差異が検出されたが，両 集団間に拈いて $\mathrm{R}_{\mathrm{ST}}$ の值が低かったのは，互いのハプロタ イプのアリルサイズが似通っていたためと考觉られた (Table 4).この結果から，YH と YA 集団間では，相互に菌 の移出入があることが示唆された. YH-E と YAの各分集団 間に拈いて有意性が劣ったのは，YH-Eの個体数が少なかっ たためであると推察された（Table 5). 。た，今回検出され た全 57 ハプロタイプのらち 35 ハプロタイプのレースを調 査した結果，レース 007.0 が 34, レース 037.1 が 1 八プロ タイプとなり，本集団のレースをハプロタイプにより識別 することは困難であると考えられた.

Minimum spanning tree による系統樹では，YA 集団を基準 として見た場合， $\mathrm{YH}$ と $\mathrm{TA}$ 集団は異なる方向に分化してい る傾向が認められた（Fig. 2)。 また, YH-Eの 4 個体のハプ
ロタイプである I-1 が YH 扎よび YA 集団全体で検出頻度の 高いハプロタイプであった（Fig. 2）ことからも，YH 固場 で早期に発生した菌が YA 圃場に移入し, 両圃場内で増殖し たことが強く示唆された.

以上のことから, いもち病菌の SSR マーカーを用いるこ とで，同一品種上など，これまで識別が困難であったいも ち病菌集団を識別できることが明らかとなった。また，近 接する圃場に打ける集団間の菌の移入を検出することがで きた.さらに，標準的な栽培管理を行った場合の感受性品 種上の菌集団の遺伝的多様性程度やその変化を, 集団遺伝 学的指標により示したことにより，栽培条件や品種抵抗性 を変化させた時の菌集団の変化を定量的に解析するための 基礎データを得ることができた.

今後は，これら SSR マーカーをいもら病菌集団構造解析 に用いることで，種子更新の前後に拈ける圃場分離菌集団 の変化, すなわち遺伝的浮動の大きさの推定や, 抵抗性品 種栽培時における非病原力遺伝子など重要形質に関わる遺 伝子の集団内で優占化の速度など，特定の栽培管理がいも ち病菌集団の変化に及ぼす影響の定量的解析が可能になる と期待される.

\section{摘 要}

近年開発されたイネいもら病菌の 12 座の SSR マーカー について，固場分離集団に対する識別能を明らかにするこ とを目的とし，「あきたこまち」が栽培されている固場 YA, $\mathrm{YA}$ と距離 $1 \mathrm{~km}$ の「またこまち」栽培圃場 TA, YA と距 離 $30 \mathrm{~m}$ の「ひとめぼれ」栽培圃場 $\mathrm{YH}$ から菌の世代別に採 集したいもち病菌の集団構造をSSR マーカーにより解析し た. 12 マーカーのらち 1 マーカーは多型がなく, 3 マーカー は世代経過時に変異する可能性が示唆されたため, 中程度 のアリル数を示す 8 マーカーを集団構造解析に用いた. 供 試した 3 圃場のいもち病菌集団および世代別分集団のハプ ロタイプ多様度は $0.535 \sim 0.904$ であり，「ひとめぼれ」発 生初期集団を除き比較的高い值を示した。圃場別の 3 集団 および世代別の 8 分集団に打けるペアワイズ $\mathrm{F}_{\mathrm{ST}}$ および $\mathrm{R}_{\mathrm{ST}}$ を算出した結果，同一圃場の分集団間では遺伝的分化は検 出されなかったが，固場別の集団はそれぞれ遺伝的に異な ることが明らかとなり，8 マーカーを用いることで，種子由 来を異にする同一品種上や，近接する圃場の異品種上のい もち病菌集団を識別できることが明らかとなった。 また， 早期に発生した菌の近接圃場への移入の検出にも SSR マー カーが有効であった。 さらに，同一品種間と隣接異品種間 を比較した場合，SSRハプロタイプに基づき作成した系統 樹から，それらの遺伝的分化の方向が異なることが明らか 
となった. 以上の結果から，本 SSR マーカーは従来識別が 困難であった同一品種間掞よび近接圃場間のいもち病菌集 団の識別に有効であるだけでなく，いもち病菌の移出入率 や遺伝的浮動の大きさの推定等, 進化的指標の評価にも適 用できることが示された。

\section{引用文 献}

Excoffier, L., Laval, G. and Schneider, S. (2005). Arlequin (version 3.0): An integrated software package for population genetics data analysis. Evol. Bioinform. Online 1: 47-50.

Fukuoka, S., Saka, N., Koga, H., Ono, K., Shimizu, T., Ebana, K., Hayashi, N., Takahashi, A., Hirochika, H., Okuno, K. and Yano, M. (2009). Loss of function of a proline-containing protein confers durable disease resistance in Rice. Science 325: 9981001.

Guichoux, E., Lagache, L., Wagner, S., Chaumeil, P., Léger, P., Lepais, O., Lepoittevin, C., Malausa, T., Revaedel, E., Salin, F. and Petit, R.J. (2011). Current trends in microsatellite genotyping. Mol. Ecol. Resour. 11: 591-611.

Hayashi, N., Inoue, H., Kato, T., Funao, T., Shirota, M., Shimizu, T., Kanamori, H., Yamane, H., Hayano-Saito, Y., Matsumoto, T., Yano, M. and Takatsuji, H. (2010). Durable panicle blastresistance gene $\mathrm{Pb1}$ encodes an atypical CC-NBS-LRR protein and was generated by acquiring a promoter through local genome duplication. The Plant J. 63: 498-510.

伊藤隆二 (1967). いもち病抵抗性品種の罹病化とその育種的 対策. 育種学最近の進歩 8: 61-66.

Jia, Y., McAdams, S.A., Bryan, G.T., Hershey, H.P. and Valent, B. (2000). Direct interection of resistance gene and avirlence gene products confers rice blast resistance. EMBO J. 19: 4004-4014.

小林次郎 (1984). 発生初期に打ける葉いもちの疫学的研究. 秋田農試研報 26: 1-84.

McDonald, B.A., Mundt, C.C. and Chen, R-S. (1996). The role of selection on the genetic structure of pathogen populations: Evidence from field experiments with Mycosphaerella graminicola on wheat. Euphytica 92: 73-80.

Nei, M. (1987). Molecular evolutionary genetics, p. 177, Columbia University Press, New York.

Peakall, R. and Smouse, P.E. (2006). GENALEX 6: genetic analysis in Excel. Population genetic software for teaching and research. Mol. Ecol. Note 6: 288-295.

坂 紀邦・寺島竹彦・工藤 悟・加藤恭宏・杉浦和彦・遠藤征馬 城田雅毅・井上正勝 - 大竹敏也 (2007)。 ( 、も ち病高度圃 場抵抗性を有する水稲新品種「夕水はるか」. 愛知農試研 報 39: 95-109.

坂 紀邦・福岡修一・寺島竹彦・工藤 悟・安東郁男・杉浦和彦・ 佐藤宏之・前田英郎・遠藤征馬・加藤博美・井上正勝 (2010). いもち病高度圃場抵抗性と極良食味特性を併せ持つ水稲新 品種「中部 125 号」の育成. 愛知農試研報 42: 171-183.

Slatkin, M. (1995). A measure of population subdivision based on microsatellite allele frequencies. Genetics 139: 457-462.

Spitze, K. (1993). Population structure in Daphnia obtusa: Quantitative genetic and allozymic variation. Genetics 135: 367-374.

Suzuki, F., Yamaguchi, J., Koba, T., Nakajima, T. and Arai, T. (2010). Changes in fungicide resistance frequency and population structure of Pyricularia oryzae after discontinuance of MBI-D fungicides. Plant Dis. 94: 329-334.

鈴木文彦・藤 晋一・古場文子・中島 隆・荒井治喜 (2012). SSR マーカーによる西日本から分離されたイネいもち病菌 の多様性と集団解析. 日植病報 78: 10-17.

高橋真実・芦澤武人・平八重一之・森脇丈治 (2008). 水田戒 場に扣けるイネいもち病菌の病原性突然変異頻度の推定. 北陸病虫研報 57: 11-17.

田中恒一・三浦春夫・平山成一・菊地市郎 (1970). 新庄市に おけるシモキタのいもち病多発生について. 北日本病虫研 報 21: 55 .

Thuillet, A.C., Bru, D., David, J., Roumet, P., Santoni, S., Sourdille, P. and Bataillon, T. (2001). Direct estimation of mutation rate for 10 microsatellite loci in durum wheat, Triticum turgidum (L.) Thell. spp durum desf. Mol. Biol. Evol. 19: 122-125.

山田信介・松本利雄・堀呈治・草野 登・橋本 晃 (1970). 福島県に打けるフクニシキの穂いもち多発生について。北 日本病虫研報 21: 54 .

山口誠之・横上晴郁・片岡知守 -中込弘二・滝田 正 ・東 正昭・ 加藤 浩 - 田村泰章 - 小綿寿志 - 小山田善三・春原嘉弘 (2005). いもち病に強い良食味水稲品種「ちゅらひかり」 の育成. 東北農研研報 104: 1-16.

Zhan, J., Mundt, C.C., Hoffer, M.E. and McDonald, B.A. (2002). Local adaptation and effect of host genotype on the rate of pathogen evolution: an experimental test in a plant pathosystem. J. Evol. Biol. 15: 634-647. 